\title{
Microbiological Study of Showerhead Waters from 10 Beaches of Great Lisboa and West Regions of Portugal
}

\author{
Estudo microbiológico de Chuveiros de 10 praias da grande Lisboa e Oeste de Portugal
}

\author{
Maria do Céu Costa ${ }^{1,2,3}$, Eva Oliveira ${ }^{1}$, Catarina Pires ${ }^{1}$, Filipa Moleiro ${ }^{1}$, Vanessa Capitia ${ }^{1}$, \\ Manuela Vida ${ }^{1,2}$ \\ 1ERISA - Escola Superior de Saúde Ribeiro Sanches, Rua do Telhal aos Olivais, n8 - 8a, 1900-693 Lisboa \\ ${ }^{2}$ CBIOS, Faculdade de Ciências e Tecnologias da Saúde, Universidade Lusófona, Campo Grande 376, 1649-024 Lisboa, \\ PORTUGAL \\ ${ }^{3}$ LNEG, Laboratório Nacional de Energia e Geologia, I.P., Estrada da Portela, Bairro do Zambujal, Apartado 7586, \\ Alfragide, 2610-999 - Amadora, PORTUGAL \\ Email: maria.costa@ulusofona.pt
}

\begin{abstract}
Many bacteria pathogenic to man can interfere in water distribution systems, forming aggregates that give rise to a complex structure called biofilm. In order to monitor the microbiological content of water from beach showers from ten sites along the coast from Lisboa-Carcavelos to Foz do Arelho beaches, 24 water samples were analyzed in 2013, 12 during January and February, and other 12 during June. The samples were collected in $500 \mathrm{~mL}$ sterile bottles with sodium thiosulfate. Biofilms were collected on swabs (at the same water sampling points) with transport medium Tween 20, and maintained between $2{ }^{\circ} \mathrm{C}$ and $4{ }^{\circ} \mathrm{C}$, such as water samples. The following microbiological parameters were investigated for water samples: total microbial count at $22{ }^{\circ} \mathrm{C}$ and $37{ }^{\circ} \mathrm{C}$, total coliforms and Escherichia coli, Pseudomonas aeruginosa, fecal streptococci, total Staphylococcus and coagulase-positive Staphylococcus. The swabs lead to the isolation of the microorganisms grown on the nutrient agar medium, in order to determine the the same microbiological parameters investigated in water showers. Globally, the water quality was found to be suitable, but that does not rule out the need for constant monitoring of the beach showers. Taking into account that there have been reports of plankton invasions and allergic eruptions after bathing in some seaside spots near Lisboa, these study results prompt us to recommend that swimmers should always shower after bathing or diving since showerheads were found safe all over the coast.
\end{abstract}

Keywords: Beach showers; Great Lisbon Region, West Region; Biofilms; Microbiological Quality.

\section{Resumo}

Muitas bactérias patogénicas podem interferir no sistema de distribuição de água formando agregados de biofilme. Com o objetivo de monitorizar a qualidade microbiológica da água dos chuveiros de praia, recolheram-se 24 amostras de água, 12 em janeiro e fevereiro, e outras 12 em junho de 2013, em 10 praias ao logo da costa Lisboa-Carcavelos a Foz do Arelho.

As amostras foram colhidas em frascos esterilizados de $500 \mathrm{~mL}$ contendo tiossulfato.

Paralelamente foram feitas zaragatoas dos mesmos pontos de colheita, com o meio de transporte Tween 20, e mantidas entre $2{ }^{\circ} \mathrm{C}$ e $4^{\circ} \mathrm{C}$. Os parâmetros microbiológicos analisados para as águas foram: quantificação de microrganismos a $22{ }^{\circ} \mathrm{C}$ e $37{ }^{\circ} \mathrm{C}$, contagem dos coliformes totais e Escherichia coli, de Pseudomonas aeruginosa, de Estreptococos fecais e de Estafilococos totais e Estafilococos coagulase-positiva. A partir das zaragatoas fez-se o isolamento dos microrganismos que cresceram no meio de Nutriente Agar, com o intuito de se determinar os mesmos parâmetros microbiológicos pesquisados na água dos chuveiros. No geral, a qualidade da água é adequada, o que não exclui a necessidade de monitorização constante dos chuveiros de praia. Tendo em conta que no $2 .^{\circ}$ período de recolha das amostras houve invasões de plâncton nalgumas destas praias estudadas e muitos banhistas apresentaram erupções alérgicas, os resultados deste estudo permitem recomendar que, após qualquer mergulho, os banhistas devem tomar sempre um duche de limpeza nos chuveiros das praias uma vez que foi evidenciada a sua segurança ao logo de toda a costa.

Palavras-Chave: Chuveiros de praia; Grande Lisboa; Região Oeste; Biofilmes; Qualidade Microbiológica 


\section{Introduction}

Many bacteria pathogenic to humans can interfere in water distribution systems (whether warm or cold), and also have the ability to adhere to internal surfaces of pipes, faucets and showerheads. These aggregates are characterized by a good organization of numerous types of microorganisms that develop in this matrix, known as biofilm. The formation occurs naturally on any solid surface in contact with non-sterile water [3]. Biofilms are normally heterogeneous in nature since they are composed of two or more species, depending on the environmental conditions. Thus, metabolism and adhesion products of a given species might help promoting ligand growth for binding other species. From another perspective, competition for nutrients and accumulation of toxic metabolites produced by colonizing species may limit the diversity of species present in the biofilm [4]. Regarding the role of biofilms in the contribution to the transmission of water-related pathogenic microorganisms, it is known that the biofilm increases as microorganisms multiply. The force of flowing water may also dislodge microorganisms and carry them throughout water distribution systems by scattering or separation processes. In this perspective, the biofilm acts as a depository, providing a continuous release of bacteria into tap water [5].

Generally, biofilms are associated to thin microbial films, millimeters or micrometers thick, although some biofilms inches thick also exist.

Thus, the biofilm is a microbial community characterized by cells [4] which:

- Are irreversibly bound to a substrate interface;

- Are embedded in a self-produced extracellular polymeric substances matrix;

- Exhibit a modified phenotype determined by growth rate and genomic transcription.

The importance of biofilms must be emphasized since these act as a critical factor in tap water contamination. Moreover, biofilms favor the formation of inner lumens in the pipe systems due to the availability of nutrients in the water and other related factors, such as its chemistry, circulation, stagnation, temperature, building materials, surface corrosion and the degree of surface displacement [5].

Biofilm composition and activity depends on numerous factors. The quality and quantity of nutrients, ions and other substances present in the environment influence the bacteria behavior. For example, the presence of certain ions, such as calcium, magnesium or zinc, lead to increased biofilm formation. The piping surface where biofilms grow also influences the microbial populations in this ecosystem. Studies have shown that biofilms de-

\section{Introdução}

Muitas bactérias patogénicas para o homem podem intervir no sistema de distribuição de água (morna ou fria), e também têm a capacidade de aderir a superfícies internas de tubagens, torneiras e chuveiros. Estes agregados são caracterizados por uma boa organização de numerosos tipos de microrganismos que se desenvolvem nesta matriz, conhecida como biofilme. A formação ocorre de forma natural em qualquer superfície sólida em contacto com a água não estéril [3].

Os biofilmes são normalmente de natureza heterogénea, uma vez que são compostos por duas ou mais espécies, dependendo das condições ambientais. Os produtos do metabolismo e da adesão de uma dada espécie podem ajudar a promover o crescimento de ligandos para a ligação de outras espécies. Noutra perspetiva, a competição por nutrientes e a acumulação de metabolitos tóxicos produzidos pelas espécies colonizadoras poderão limitar a diversidade de espécies presentes no biofilme [4].

Relativamente ao modo como o biofilme contribui para a transmissão de microrganismos patogénicos relacionados com a água, sabe-se que à medida que os microrganismos se multiplicam no biofilme, este aumenta. Por sua vez, as forças da água corrente quebram fragmentos que podem conter microrganismos transportando-os ao longo do sistema de distribuição da água por processos de dispersão, separação, entre outros. Nesta perspetiva o biofilme atua como depósito para a libertação contínua de bactérias na água corrente [5].

Geralmente os biofilmes associam-se a "filmes" microbianos de espessuras finas, da ordem dos milímetros ou dos micrómetros, mas também existem biofilmes que podem atingir os centímetros de espessura.

O biofilme é, portanto, uma comunidade microbiana caracterizada por células que [4]:

- Se encontram irreversivelmente ligadas a um substrato, interface ou aos dois;

- Estão embutidos numa matriz de substâncias poliméricas extracelulares por eles produzidas;

- Exibem um fenótipo alterado devido à taxa de crescimento e transcrição genómica.

Salienta-se a importância de biofilmes na água na medida em que constituem um fator crítico no que respeita à contaminação da água da torneira, para além de que propiciam a formação de lúmens internos nos sistemas de tubagens devido à disponibilidade de nutrientes na água e a outros fatores com ela relacionados, como sejam, a sua química, circulação, estagnação, temperatura bem como superfície dos materiais de construção, grau de corrosão da superfície e grau de desalojamento da superfície [5].

A formação de biofilmes está dependente de inúmeros fatores. A qualidade e quantidade de nutrientes, iões e outras substâncias presentes no ambiente influenciam o comportamento das bactérias, podendo certamente ter 
velopment is faster in iron surface pipes than PVC plastic and that iron pipes support more diverse microbial populations [6]. Regarding the microbial colonization, however, one should note that the surface components are less important than the biofilm-surface relationship. Biofilms may also be viewed as acting as biological filters by the mineralization of the biodegradable organic material and formation of a locally immobilized biomass.

Therefore, one might extrapolate that the proliferation of pathogenic microorganisms being formed in these biofilms may influence the quality of the water and may be a risk to public health.

The shower aerosol particles might be small enough to carry bacteria into the respiratory airways. Pulmonary diseases and other health risks such as asthma, bronchitis, and hypersensitivity pneumonia, are associated with inhalation of bacteria and microorganisms or related components [1]. Immunocompromised populations are growing, meaning that the identification of potential pathogenic reservoirs is a major public health concern [2]

The present work aims to contribute to the knowledge on the microbiological quality of the water in showerheads of well-known highly frequented Portuguese beaches in the areas of Cascais district, in the Great Lisbon Region, and of Torres Vedras and Caldas da Rainha districts, in the West.

\section{Material and Methods}

\section{Type of Search}

This study involves a qualitative, longitudinal and exploratory analysis conducted during 2012/2013 at the Ribeiro Sanches School of Health (ERISA).

\section{Procedures}

Samples were obtained from the Water Supply Network. Water samples were collected during the months of January, February and June 2013, from five showers in Carcavelos Beach, three at the Santo Amaro de Oeiras Beach, two at S. Pedro do Estoril Beach, one at Cascais Beach, two at The Beach of Physics, two at Formosa Beach, one at Blue Beach, four at Santa Rita uma função regulatória no que respeita à formação destas estruturas. Por exemplo, a presença de determinados iões como o cálcio, magnésio ou zinco que quando presentes proporcionam um aumento do biofilme.

A superfície da tubagem em que se estabelece o biofilme também influencia a composição e atividade microbiana das populações existentes neste ecossistema. Estudos têm demonstrado que o desenvolvimento de biofilmes é mais rápido em superfícies de ferro do que em tubagens de plástico $\mathrm{PVC}$, e que a primeira superfície suporta a presença de uma população microbiana mais diversa [6]. No que respeita à colonização pelos microrganismos destaca-se que o material que compõe a superfície é de menor importância que a relação biofilme-superfície.

Por um lado, os biofilmes atuam como filtros biológicos pela mineralização de material biológico biodegradável e formam biomassa imobilizada localmente.

Pode-se assim dizer que a proliferação de microrganismos patogénicos, que se formam nestes biofilmes, vão influenciar a qualidade da água e causar riscos para a Saúde Pública.

As partículas de aerossóis do chuveiro podem ser suficientemente pequenas para transportar bactérias até às vias respiratórias. Doenças pulmonares e outros riscos de saúde, tais como asma, bronquite, pneumonia de hipersensibilidade estão associados à inalação de bactérias e microrganismos ou dos seus componentes [1]. As populações imunocomprometidas estão em ascensão, pelo que a identificação de reservatórios de patogénicos potenciais é uma preocupação de saúde pública. [2] O presente trabalho tem como objetivo contribuir para o conhecimento sobre a qualidade microbiológica da água em chuveiros de praias portuguesas muito frequentadas nos locais do concelho de Cascais, como sendo a Região da Grande Lisboa e nos concelhos de Torres Vedras e Caldas da Rainha, como sendo a Região Oeste de Portugal.

\section{Material e Métodos}

\section{Tipo de Pesquisa}

Este estudo apresenta uma análise qualitativa, longitudinal e exploratória com análises laboratoriais realizadas durante o ano letivo 2012/2013 da Escola de Saúde Ribeiro Sanches (ERISA).

\section{Procedimentos}

As amostras foram obtidas a partir da Água da Rede de Abastecimento.

Foram recolhidas durante o mês de Janeiro, Fevereiro e Junho de 2013, sendo 5 chuveiros de praia de Carcavelos, 3 da praia de Santo Amaro de Oeiras, 2 da praia de S. Pedro do Estoril, 1 da praia de Cascais, 2 da praia da 
Beach, two at Foz do Arelho Band two at The Beach of Consolation, totaling 24 samples. The sampling occurred in two phases, that is, two sets of 12 samples were collected. Figure 1

A minimum volume of $500 \mathrm{~mL}$ per sample was col-
Física, 2 da praia Formosa, 1 da praia Azul, 4 da praia de Santa Rita, 2 da Praia da Foz do Arelho, e 2 da praia da Consolação, totalizando 24 amostras.

As amostras foram recolhidas num volume mínimo de $500 \mathrm{~mL}$ em frascos de vidro previamente esterilizados,

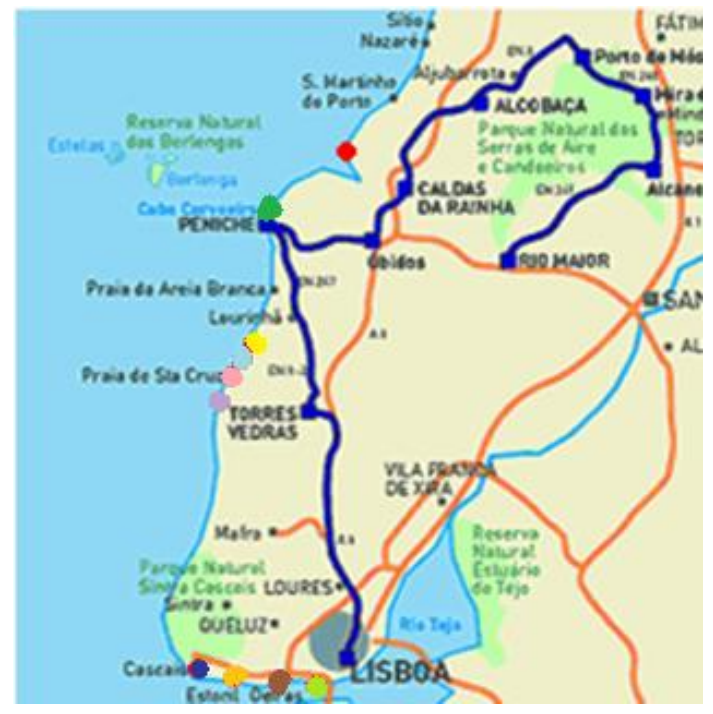

Legend/Legenda:

- Foz do Arelho

- Consolação

Santa Rita

Azul

Formosa

- Física

- Cascais

S. Pedro do Estoril

- Santo Amaro de Oeiras

Carcavelos

Figure 1 / Figura 1 - Beach Localities of Sample Collections

Mapa Ilustrativo das Praias de Recolha das Amostras

lected in sterilized glass vials with $0.5 \mathrm{~mL}$ of sodium thiosulfate $1.8 \mathrm{cL} / \mathrm{L}$. After the collection procedure, bottles were packed in insulated boxes and immediately transported for analysis.

Biofilms for analysis were obtained by swabbing the inner surface of the beach shower. Subsequently these were left to grow in a Nutrient Agar medium. The biofilm was collected with the help of a swab that was placed thereafter in transport medium Tween 20 to the laboratory (also in isothermal box material), where it was plated on TSA medium (solid medium) and incubated at $30^{\circ} \mathrm{C}$ and $40^{\circ} \mathrm{C}$ for 3 days.

In the laboratory, the filtering membrane technique protocol was adapted by using a sterile membrane $(0.45$ $\mu \mathrm{m})$ placed between the funnel and its support, with the crosslinked surface facing upwards, in order to detect and quantify coliform bacteria, E. coli, fecal streptococci, and total coagulase positive staphylococci along with Pseudomonas aeruginosa. For each water sample a set of sterile filtration (hopper / support) was used. With the help of a flamed forceps a sterile membrane $(0.45 \mu \mathrm{m})$ was glued between the hopper and support. Filtration of about $100 \mathrm{~mL}$ of the sample was followed by membrane remove again with a flamed forceps and further placement on a growing medium suitable for contendo $0,5 \mathrm{~mL}$ de solução de tiossulfato de sódio a $1,8 \mathrm{cL} / \mathrm{L}$.

Após o procedimento de recolha de água, as garrafas foram acondicionadas em caixas de material isotérmico e transportadas imediatamente para serem analisadas. Os biofilmes para serem analisados, foram obtidos por passagem de zaragatoas na superfície interior dos chuveiros das praias e posteriormente foram cultivados no meio de Nutriente Agar. O biofilme foi recolhido com ajuda da zaragatoa que foi colocada no meio de transporte Tween 20 até ao laboratório, também em caixa de material isotérmico, onde foi semeado em meio TSA (meio sólido) e incubado a $30{ }^{\circ} \mathrm{C}$ e a $40{ }^{\circ} \mathrm{C}$ durante 3 dias.

Após o procedimento de recolha de água, as garrafas foram acondicionadas em caixas de material isotérmico e transportadas imediatamente para serem analisadas.

No laboratório adequou-se o protocolo da técnica membranas filtrantes, com a colocação de uma membrana estéril entre o funil e o seu suporte, com o reticulado virado para cima $(0,45 \mu \mathrm{m})$, para a pesquisa e quantificação de Bactérias coliformes, E. coli, Estreptococos fecais, Estafilococos totais e com reação coagulase positiva e ainda Pseudomonas aeruginosa, bem como o protocolo da Metodologia de Incorporação para a Contagem total de microrganismos a $22^{\circ} \mathrm{C}$ e $37^{\circ} \mathrm{C}$.

Para cada amostra de água utilizou-se um conjunto de 
each parameter under study. Four filtrations per sample were performed.

The merger methodology protocol for total mesophile microbial count at $22{ }^{\circ} \mathrm{C}$ and $37{ }^{\circ} \mathrm{C}$ was also applied. The use of reference methods, in accordance with the ISO standards as mentioned in Table 1 below ensures the required harmonization of the results.

\section{Results and Discussion}

The concept of water quality is relative, since it depends on the intended use or purpose of the user. Thus, for specific purposes, the water quality may be defined as the set of physical, chemical and biological properties adequate to its use. It is therefore necessary to set out adequate quality requirements for each purpose, that is, to set quality parameters and respective limits. These limits refer to the maximum permissible limits of pathogen microorganisms which can exist because if they exceed these values shall be taken that indicate that we are facing a water unfit for the use for which it is intended. The present work was directed to the study of the microbiological quality of beach water showers, considering parameters also used for the analysis of pool water in accordance with the bacteriological parameters established at the Annex I of the Portuguese Regulatory Decree 5/97. During the research period, the project scope was limited to the available laboratory conditions. The study aim consisted in knowing if the showers, all or in part, had the minimal bacteriological conditions required for their use.

This study was of particular interest, as in the summer of 2013 unusually high concentrations of microalgae were detected in many Lisbon region beaches. By then attendants were strongly advised to shower after any contact with seawater for their safety. By evaluating this water quality, we will know if objective information regarding the importance of beach showering will be reinforced, or if, on the contrary, it will be necessary to invest in a cleansing operation.

In our study, the majority of microorganisms found in water showers are $37^{\circ} \mathrm{C}$ mesophilic and Pseudomonas spp. (Table 2 and 3 and Figure 2 and 3 ). Basically there was growth of mesophilic at $37^{\circ} \mathrm{C}$ and Pseudomonas $\mathrm{sp}$, but both are within the range of maximum permissible limits. Thus, the detected Pseudomonas spp. will not cause any problems in human health.

Existing mesophilic have optimal growth at $37^{\circ} \mathrm{C}$. Usually mesophilic match most of the pathogens of interest, but in this study it was observed that there was no filtração estéril (funil/suporte). Com ajuda de uma pinça flamejada colocou-se uma membrana estéril $(0,45 \mu \mathrm{m})$ entre o funil e o suporte. Filtrou-se cerca de $100 \mathrm{~mL}$ da amostra, e após a filtração retirou-se a membrana novamente com uma pinça flamejada e colocou-se sobre o meio de cultura adequado para cada parâmetro em estudo, realizando-se 4 filtrações por amostra.

A utilização dos métodos de referência, de acordo com as normas ISO como referenciados na Tabela 1 abaixo, assegura a necessária harmonização dos resultados.

\section{Resultados e Discussão}

O conceito de qualidade da água é relativo, já que depende do uso a que se destina ou do objetivo do seu utilizador. Assim, a qualidade da água pode ser definida, para fins específicos, como o conjunto de características físicas, químicas e biológicas adequadas à sua utilização para determinado uso. Para cada uso da água é pois necessário estabelecer as exigências relativas à sua qualidade, isto é, definir parâmetros de qualidade e estabelecer os seus valores-limite. Estes limites referemse aos limites máximos admissíveis de microrganismos patogénicos que podem existir, pois caso ultrapassem esses valores ter-se-á que indicar a possibilidade de estarmos perante uma água imprópria para o uso a que se destina.

Direcionou-se este trabalho para o estudo da qualidade microbiológica da água de chuveiros de praias, com os parâmetros que são analisados para água de piscina, de acordo com o Anexo I do Decreto- Regulamentar 5/97. Ao longo do período de investigação, o projeto foi sofrendo alguns ajustes de forma a adequá-lo às condições de trabalho disponíveis, tendo-se definido como objetivos da investigação saber se todos os chuveiros ou apenas parte dos chuveiros analisados reúnem as condições bacteriológicas mínimas exigidas para a sua utilização.

Este estudo torna-se de interesse relevante, uma vez que, no Verão de 2013, apareceram microalgas na água do mar de muitas praias populares da região de grande Lisboa e foi aconselhado a todos os banhistas fazerem uma passagem por água doce, após qualquer contato com a água do mar, através dos chuveiros disponíveis nos recintos balneares. Assim, saber se nos chuveiros as análises da água evidenciam se esta se encontra ou não com boa qualidade, permitirá ou não transmitir segurança ao banhista e incentivar mais o uso destes chuveiros por banhistas que ainda não são adeptos a este hábito ou, pelo contrário, atuar em campanhas de limpeza.

$\mathrm{Na}$ nossa pesquisa, a maioria dos microrganismos encontrados na água dos chuveiros são mesófilos a $37^{\circ} \mathrm{C}$ e Pseudomonas sp. (Tabela II, III e IV e Figura 2 e 3). Basicamente houve crescimento de mesófilos a $37^{\circ} \mathrm{C}$ e de Pseudomonas spp., mas ambos encontram-se dentro dos valores admissíveis. Portanto, as Pseudomonas spp. detectadas não vão causar 
Table I / Tabela I . Bacteriological Analyzes / Análises bacteriológicas

\begin{tabular}{|c|c|c|}
\hline Parâmetros/ Parameters & $\begin{array}{lr}\text { Valor } & \text { recomendado } \text { UFC }^{*} \\
/ \text { CFU* }^{*} & \text { Recommended } \\
\text { Value } & \end{array}$ & $\begin{array}{l}\text { Valores limite de } \text { UFC }^{*} \\
/ \text { CFU }^{*} \text { Limit Values }\end{array}$ \\
\hline $\begin{array}{l}\text { Total Coliformes/ Coliforms } \\
\text { Escherichia coli } \\
\text { Estreptococos fecais } \\
\text { Pseudomonas aeruginosa } \\
\text { Total de Staphylococcus...... } \\
\text { Staphylococcus } \\
\text { produtores de } \\
\text { coagulase/coagulase } \\
\text { producers } \\
\text { Microrganismos viáveis em } \\
\text { meio nutritivo gelosado, em } \\
\text { aerobiose, a } 37^{\circ} \mathrm{C} / \text { Viable } \\
\text { microorganisms in a nutrient } \\
\text { medium under aerobic } \\
\text { conditions at } 37^{\circ} \mathrm{C}\end{array}$ & $\begin{array}{l}0 / 100 \mathrm{ml} \\
- \\
- \\
- \\
<20 / 100 \mathrm{ml} \\
0 / 100 \mathrm{ml} \\
\\
<100 / \mathrm{ml} \text { às } 24 \mathrm{~h} / \text { after } 24 \mathrm{~h}\end{array}$ & \begin{tabular}{|c|}
$10 / 100 \mathrm{ml}$ \\
$0 / 100 \mathrm{ml}$ \\
$0 / 100 \mathrm{ml}$ \\
$0 / 100 \mathrm{ml}$ \\
$(1)$ \\
$0 / 100 \mathrm{ml} \mathrm{em} 90 \%$ das \\
amostras \\
$0 / 100 \mathrm{ml}$ \\
\\
\end{tabular} \\
\hline
\end{tabular}

UFC* / CFU : unidades formadoras de colónias / colony forming units

(1) The recommended value may be exceeded once a time of public opening / Poder-se-á ultrapassar o valor recomendado uma vez por época de abertura ao público

Note/ Nota - The methods used in the determinations must follow officially recognized standards (e.g. NP, CEN, AFNOR, ISO or Standard Methods for Water and Wastewater) or own validated methods / Os métodos usados nas determinações devem seguir normas oficialmente reconhecidas (exemplo: NP, CEN, AFNOR, ISO ou Standard Methods for Water and Wast Water) ou ainda métodos próprios validados.

growth of coliforms, E. coli, fecal streptococci and $S$. aureus, reason why one can conclude that other mesophilic microorganisms that are present in the evaluation of water quality have no great importance. It must also be borne in mind that the water in question is not a sterile product, and as such Microorganisms are expected to be encountered.

Although in the sample 13 grew 2 colonies of Pseudomonas spp. in the biofilm, and 1 colony of Pseudomonas spp. in the water, this growth has no clinical relevance to human health since it is a non-sterile water, meaning that a few acceptable microorganisms may be present, as long as within the acceptable limits for human health.

In summary, biofilms have revealed no meaningful microbiological growth (Table II, III and IV), meaning that the showers do not offer favorable conditions for problemas na saúde humana. Os mesófilos existentes têm um desenvolvimento ótimo a $37^{\circ} \mathrm{C}$. Normalmente os mesófilos correspondem à maioria dos patogénicos de interesse, mas neste estudo observou-se que não houve crescimento de coliformes, E. coli, Estreptococos fecais e $S$. aureus, pelo que se pode concluir que os mesófilos presentes são outros microrganismos que na avaliação da qualidade da água não apresentam grande importância. Também tem que se ter em conta que a água em análise não é um produto estéril, e como tal é expectável a presença de microrganismos.

Este crescimento não tem importância clínica na saúde dos utilizadores, pois trata-se de uma água não estéril, o que significa que existem determinados microrganismos que desde que se encontrem dentro dos valores limite não acarretam qualquer problema à saúde pública.

Embora na amostra 13 tenha ocorrido crescimento de 2 colónias de Pseudomonas spp. no biofilme, e 1 colónia de Pseudomonas spp. na água, pode-se concluir que 
common pathogen bacteria growth, and therefore do not contribute, in these conditions, to water contamination. oos biofilmes não apresentaram crescimento microbiológico significativo, o que significa que os chuveiros não reúnem as condições favoráveis ao crescimento

Table II /Tabela II- Means and standards used for the determination of microbiological parameters

Meios e padrões utilizados para a determinação dos parâmetros microbiológicos

\begin{tabular}{|c|c|c|}
\hline Means used & Microbiological parameters & Methodology Used \\
\hline Agar/Plate Count Agar & $\begin{array}{c}\text { Mesófilos/Mesophilic at } 22^{\circ} \mathrm{C} \\
\text { and } 37^{\circ} \mathrm{C}\end{array}$ & ISO 6222:1999 \\
\hline $\begin{array}{l}\text { Meio de m-Laurilsulfato Agar } \\
\text { /m-Lauryl Sulphate Agar }\end{array}$ & Coliform(e)s, E.coli & ISO 9308: 2000 mod. \\
\hline $\begin{array}{c}\text { Meio SLANETZ e BARTLEY } \\
\text { (base)/Slanetz Agar Base }\end{array}$ & $\begin{array}{c}\text { Estreptococos fecais/Fecal } \\
\text { streptococci }\end{array}$ & ISO $7899 / 2: 2000$ \\
\hline $\begin{array}{l}\text { Meio MSA / Manitol Salt } \\
\text { Phenol Red Agar }\end{array}$ & $\begin{array}{c}\text { Estafilococos totais Coagulase } \\
+/ \text { Total staphylococci } \\
\text { Coagulase positive }\end{array}$ & NP 4343:1998 \\
\hline $\begin{array}{c}\text { Pseudomonas Agar Base + } \\
\text { CN/ CN Agar }\end{array}$ & Pseudomonas aeruginosa & ISO 16266:2006 \\
\hline
\end{tabular}

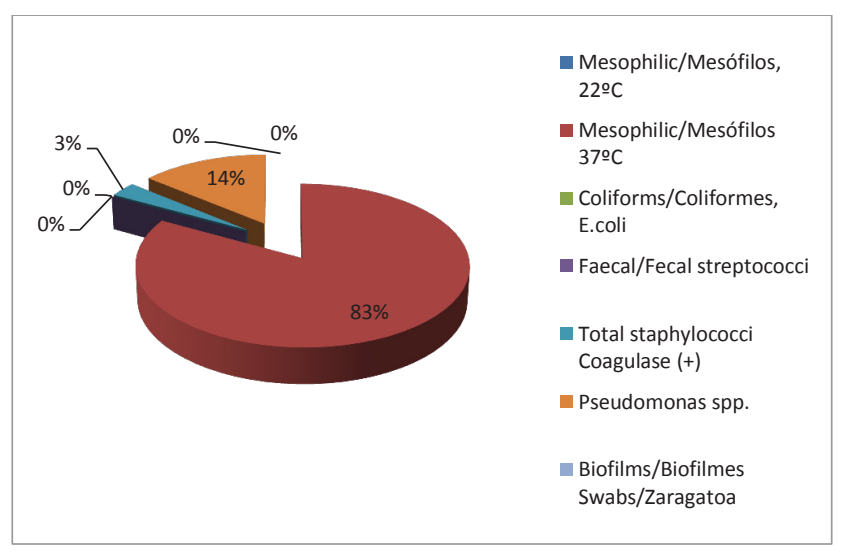

Figure 2/ Figura 2- Relative Average Percentage (First set of 12 samples).

Percentagem da Média Relativa (Primeira série de 12 amostras).

All the water studied has been subjected to chlorine treatment, as it is in the public supply network, and this is thought to have a direct influence on the microorganism content by preventing growth. Our study highlights the quality of the water from the analyzed showerheads, offering total confidence to consumers for safe usage. Published references do not refer any similar results, although one case involving the presence of Mycobacterium spp., a causative agent of tuberculosis and leprosy, detected in the showers of a United States hospital is mentioned ${ }^{[1]}$

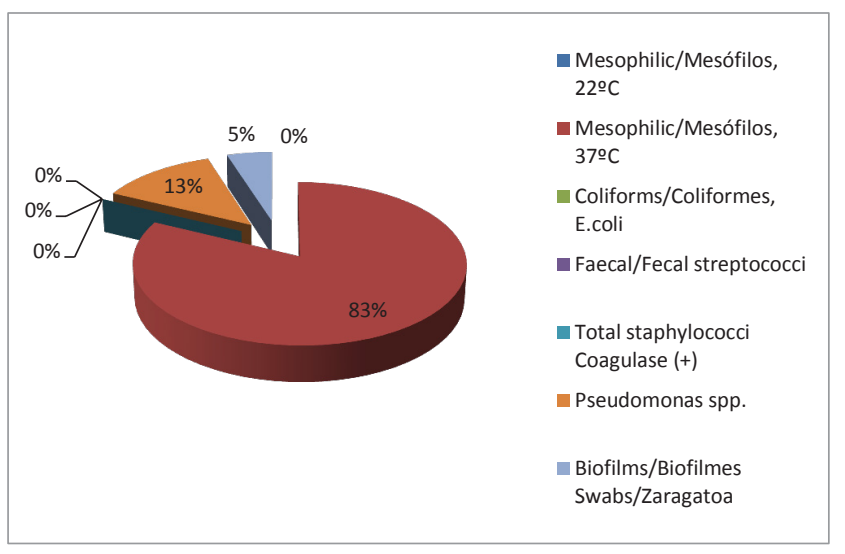

Figure 3 / Figura 3 - Relative Average Percentage (Second set of samples).

Percentagem da Média Relativa (Segunda série de 12 amostras).

das bactérias patogénicas em estudo, e assim não contribuem para contaminação da água quando perante a sua passagem. Como toda a água da rede possui cloro, pensa-se que este poderá ter tido uma interferência direta nos microrganismos, impedindo o seu desenvolvimento. Assim, este estudo evidencia a qualidade da água proveniente dos chuveiros analisados, dando assim uma total confiança aos banhistas para o uso dos mesmos. $\mathrm{Na}$ literatura consultada não foram encontrados estudos idênticos, apenas um caso discutido nos Estados Unidos, em que foi detetada a presença de Mycobacterium spp., um agente causador da tuberculose e lepra, mas nos chuveiros de um hospital. [1] 
Table III / Tabela III - Results Obtained and Respective Average (First set of 12 samples)

Resultados Obtidos e Respetiva Média (Primeira série de 12 amostras)

\begin{tabular}{c|c|c|c|c|c|c|c|c|c|c|c|c|c|c|}
\cline { 2 - 11 } & \multicolumn{10}{c|}{ Samples/ Amostras } & \multicolumn{1}{c|}{} \\
\hline $\begin{array}{c}\text { Parameter/ } \\
\text { Parâmetro }\end{array}$ & $\mathbf{1}$ & $\mathbf{2}$ & $\mathbf{3}$ & $\mathbf{4}$ & $\mathbf{5}$ & $\mathbf{6}$ & $\mathbf{7}$ & $\mathbf{8}$ & $\mathbf{9}$ & $\mathbf{1 0}$ & $\mathbf{1 1}$ & $\mathbf{1 2}$ & $\begin{array}{c}\text { Average/ } \\
\text { Média }\end{array}$ \\
\hline $\begin{array}{c}\text { Mesophilic/ } \\
\text { Mesófilos, } 22^{\circ} \mathrm{C}\end{array}$ & 0 & 0 & 0 & 0 & 0 & 0 & 0 & 0 & 0 & 0 & 0 & 0 & 0 \\
\hline $\begin{array}{c}\text { Mesophilic/ } \\
\text { Mesófilos, 37 }{ }^{\circ} \mathrm{C}\end{array}$ & 0 & 110 & 18 & 33 & 1 & 4 & 2 & 2 & 2 & 0 & 0 & 0 & 14 \\
\hline $\begin{array}{c}\text { Coliforms/ } \\
\text { Coliformes, E.coli }\end{array}$ & 0 & 0 & 0 & 0 & 0 & 0 & 0 & 0 & 0 & 0 & 0 & 0 & 0 \\
\hline $\begin{array}{c}\text { Faecal/ Fecais } \\
\text { streptococci }\end{array}$ & 0 & 0 & 0 & 0 & 0 & 0 & 0 & 0 & 0 & 0 & 0 & 0 & 0 \\
\hline $\begin{array}{c}\text { Total staphylococci } \\
\text { Coagulase (+) }\end{array}$ & 2 & 0 & 0 & 0 & 1 & 0 & 0 & 2 & 2 & 0 & 0 & 0 & 1 \\
\hline Pseudomonas spp. & 0 & 0 & 0 & 0 & 1 & 4 & 2 & 5 & 10 & 6 & 0 & 0 & 2 \\
\hline $\begin{array}{c}\text { Biofilms/ Biofilmes } \\
\text { Swabs/ Zaragatoas }\end{array}$ & 0 & 0 & 0 & 0 & 0 & 0 & 0 & 0 & 0 & 0 & 0 & 0 & 0 \\
\hline
\end{tabular}

Notes / Notas: ${ }^{1}$ - Despite the growth of colonies of staphylococci total, none of the colonies were coagulase positive staphylococci;

2 - Despite the growth of Pseudomonas aeruginosa colonies suspected, confirmatory testing revealed Pseudomonas aeruginosa were not present in the samples.

1 - Apesar do crescimento de colónias de Estafilococos totais, nenhuma das colónias é Estafilococos coagulase positiva;

2 - Apesar do crescimento de colónias suspeitas de Pseudomonas aeruginosa, os testes confirmatórios revelaram não estarem presentes Pseudomonas aeruginosa nas amostras.

\section{Conclusion}

According with the current national laws (Decree-Law $\mathrm{N}^{\mathrm{o}}$ 5/97- annex I), the set of bacteriological parameters here applied is mandatory to monitor the water quality in locations accessed by general consumers. This study also aimed to determine if the water in showerheads contained any relevant biofilm related contamination which could form on the inside of the showerheads and, if necessary, to implement specific risk prevention actions.

The obtained results have demonstrated the conformity of water from these showerheads, underlining the importance of preventive measures such as network maintenance, regular microbiology analysis, and residual chloride control. The absence of bacteria indicating fecal contamination, Pseudomonas aeruginosa, and coagulase positive staphylococci, along with the less than significant growth of mesophilic bacteria $\left(22{ }^{\circ} \mathrm{C}\right.$ to $37^{\circ} \mathrm{C}$ ) lead us to conclude that the water in the general supply system is properly treated, meaning a very low contamination risk. As shown, water in the showerheads is not contaminated by biofilms, and these do not show any pathogenic bacteria growth.

In light of these microbiological analysis, with all results within the established limits, we conclude that the water from the studied showerheads offers a good quality standard. In these conditions, the use of these showers by the consumer should be encouraged and recommended since this is an adequate way means to
Table IV/ Tabela IV - Results Obtained as Average Values (Second set of 12 samples).

Resultados Obtidos (Segunda série de 12 amostras).

\begin{tabular}{|c|c|c|c|c|c|c|c|c|c|c|c|c|c|}
\hline \multirow[b]{2}{*}{$\begin{array}{l}\text { Parameter/ } \\
\text { Parâmetro }\end{array}$} & \multicolumn{12}{|c|}{ Samples/ Amostras } & \multirow[b]{2}{*}{$\begin{array}{l}\text { Average/ } \\
\text { Média }\end{array}$} \\
\hline & 13 & 14 & 15 & 16 & 17 & 18 & 19 & 20 & 21 & 22 & 23 & 24 & \\
\hline $\begin{array}{c}\text { Mesophilic/ } \\
\text { Mesófilos, } 22^{\circ} \mathrm{C} \\
\end{array}$ & 0 & 0 & 0 & 0 & 0 & 0 & 0 & 0 & 0 & 0 & 0 & 0 & 0 \\
\hline $\begin{array}{c}\text { Mesophilic/ } \\
\text { Mesófilos, } 37^{\circ} \mathrm{C}\end{array}$ & 0 & 0 & 0 & 33 & 0 & 0 & 0 & 0 & 0 & 0 & 0 & 0 & 3 \\
\hline $\begin{array}{c}\text { Coliforms/ } \\
\text { Coliformes, E.coli }\end{array}$ & 0 & 0 & 0 & 0 & 0 & 0 & 0 & 0 & 0 & 0 & 0 & 0 & 0 \\
\hline $\begin{array}{l}\text { Streptococci } \\
\text { faecal/ fecais }\end{array}$ & 0 & 0 & 0 & 0 & 0 & 0 & 0 & 0 & 0 & 0 & 0 & 0 & 0 \\
\hline $\begin{array}{c}\text { Total staphylococci } \\
\text { Coagulase }(+)\end{array}$ & 0 & 0 & 0 & 0 & 0 & 0 & 0 & 0 & 0 & 0 & 0 & 0 & 0 \\
\hline Pseudomonas spp. & 3 & 1 & 0 & 0 & 1 & 0 & 0 & 0 & 0 & 0 & 0 & 0 & 0 \\
\hline $\begin{array}{l}\text { Biofilms/Biofilmes } \\
\text { Swabs/Zaragatoa }\end{array}$ & 2 & 0 & 0 & 0 & 0 & 0 & 0 & 0 & 0 & 0 & 0 & 0 & 0 \\
\hline
\end{tabular}

Notes / Notas: ${ }^{1}$ - Despite the growth of colonies of staphylococci total, none of the colonies were coagulase positive staphylococci;

2 - Despite the growth of Pseudomonas aeruginosa colonies suspected, confirmatory testing revealed Pseudomonas aeruginosa were not present in the samples.

1 - Apesar do crescimento de colónias de Estafilococos totais, nenhuma das colónias é Estafilococos coagulase positiva

2 - Apesar do crescimento de colónias suspeitas de Pseudomonas aeruginosa, os testes confirmatórios revelaram não estarem presentes Pseudomonas aeruginosa nas amostras.

\section{Conclusão}

De acordo com a Legislação em vigor (Decreto Regulamentar - 5/97- anexo I), é obrigatória a análise dos parâmetros bacteriológicos aqui estudados para verificar se a qualidade da água proveniente do chuveiro público se encontra em boas condições. Por outro lado, neste estudo, também se pretendeu verificar se a água sofre alguma contaminação por eventual biofilme que se possa formar no interior dos chuveiros e, caso fosse necessário, pôr em prática determinadas medidas de prevenção de riscos.

Perante os resultados obtidos que mostram conformidade das águas de chuveiros analisadas, é de salientar a importância dos cuidados preventivos como a manutenção das estruturas de canalização, a monitorização de análises microbiológicas e o controlo do cloro residual utilizado no tratamento destas águas.

A ausência de crescimento de bactérias indicadoras de contaminação fecal, Pseudomonas aeruginosa, Estafilococos coagulase positiva bem como o crescimento muito pouco significativo das bactérias mesófilas $\left(22^{\circ} \mathrm{C}\right.$ e 37 ${ }^{\circ} \mathrm{C}$ ), leva a crer que o processo de tratamento da água das redes de abastecimento que abrangem as zonas estudadas é eficaz e que, desta forma, a transmissão de doenças através deste meio é muito baixa. Verifica-se também que a água dos chuveiros não sofre contaminação pelo biofilme e os mesmos não apresentam crescimento de bactérias patogénicas.

Em resumo, perante os resultados de análise microbiológica obtidos, que se encontram dentro das normas estipuladas, as águas dos chuveiros das praias estudadas oferecem um bom padrão de qualidade.

De salientar que, uma vez comprovada a qualidade micro- 
prevent and reduce risks associated to skin mucosa and scalp sea related allergies.

\section{Conflict of interests}

The authors declare that there are no financial or personal affiliations that could be viewed as a potential conflict of interests. biológica da água dos chuveiros das praias em questão, o uso desses chuveiros por parte dos banhistas deve ser incentivado e recomendado na medida em que desta forma se podem reduzir os riscos associados a alergias balneares e outros envolvendo, a pele, as mucosas e o couro cabeludo.

\section{Conflito de interesses}

Os autores declaram que não existem relações financeiras ou pessoais que puderam ser vistas como um potencial conflito de interesses. 


\section{References / Referências}

[1] - Sarah D. Perkins, 1 Jennie Mayfield,2 Victoria Fraser,3 and Largus T. Angenent4 Potentially Pathogenic Bacteria in Shower Water and Air of a Stem Cell Transplant Unit Department of Energy, Environmental \& Chemical Engineering, Washington University, St Louis, Missouri 631301; Hospital Epidemiology \& Infection Prevention, Barnes-Jewish Hospital, St. Louis, Missouri 631082; Division of Infectious Disease, Washington University School of Medicine, St. Louis, Missouri 631083; and Department of Biological and Environmental Engineering, Cornell University, Ithaca, New York 148534 ;
[2] - EPAL. In: http://www.epal.pt/epal/; accessed on: December 201

[3] - Water in the healthcare setting can be the carrier of morbidity and mortality. In: http:// www.pall.com/healthcarewater.asp; accessed on: march 2012

[4] - Pedley, S., et al. (2004) Pathogenic Mycobacteria in Water: A Guide to Public Health Consequences, Monitoring and Management. World Health Organization, IWA Publishing, London: ISBN 184339059 0;
[5] - World Health Organization, (2004). Guidelines for Drinking Water Quality: Recommendations, Geneva, Volume 1, Third Edition; accessed at: http://www.who.int/ water_sanitation_health/dwq/gdwq3_contents.pdf

[6] - http://www.alandbiopharmaceuticalresearch com/Guidelines.html. accessed on march 2012 